\title{
Leadership Development in Rural Schools: An Innovative Training Model
}

\author{
Bonnie C. Fusarelli, Lance D. Fusarelli \\ North Carolina State University, USA
}

\begin{abstract}
Educational systems in nations throughout the world, including the United States, face the challenge of hiring and retaining excellent school leaders willing to serve in rural school settings. Common challenges include few qualified applicants, a lack of resources and support, impoverished communities with high unemployment and concentrated poverty, lower pay, and fewer social and cultural opportunities. Given how many schools are located in rural areas, and how critical school principals are to school improvement, attracting and retaining high quality leaders is of critical importance. In this article, we describe an innovative leadership development model specifically designed to prepare school leaders to work in rural contexts. We detail the core components of this model, distinguish it from traditional models of leadership preparation, provide preliminary evidence of the model's effectiveness, and offer lessons learned from the process. We conclude that such models can be effective in creating cadres of leaders equipped to work in rural school systems, which will help address this critical leadership challenge.
\end{abstract}

\section{Introduction}

In our increasingly interconnected, modern age, it is easy to forget that a still-sizeable population of students throughout the world attend schools in rural areas. For example, nearly one-third of schools in the United States are located in rural areas. North Carolina ranks second in the nation in both the absolute number $(685,409)$ and highest percentage $(47.2 \%)$ of rural students, with over half of the state's schools serving rural communities. It is not uncommon for low performing schools to be clustered in rural areas-the lowest performing schools in North Carolina are disproportionately found in the northeast region of the state.

Not surprisingly, rural school systems often struggle to attract and retain highly qualified teachers and school leaders, who are often lured away by offers of greater pay, better healthcare, better housing, and more sociocultural opportunities found in more urbanized areas. Rural districts suffer disproportionately from poverty and higher unemployment compared to their more affluent urban and suburban peers. Many rural districts also suffer from high concentrations of intergenerational poverty and unemployment. Taken together, the 14 counties in rural, Northeast North Carolina would rank number one in the state for the highest rates of teen pregnancy, infant mortality, and other deficit metrics. Additionally, the vestiges of racial segregation remain distinctive in these communities and their institutions. Students experience stark racial and socioeconomic isolation. For example, Halifax County in northeast North Carolina is 39 percent White overall, however the Halifax County Public Schools are almost 100 percent non-White. The school district's free and reduced lunch (FRL) percentages, the standard measure of poverty in schools, are well over 90 percent. The schools in these communities are further disadvantaged by the lack of opportunity, including jobs and social and cultural attractions, as well as fewer healthcare resources.

The northeast districts are further negatively impacted by North Carolina's school funding formula which allows wealthier school systems to provide additional supplements to the state base salary for educators. Due to their smaller tax base, rural counties offer minimal to no supplement resulting in lower principal salaries compared to wealthier urban districts. With a reduced tax base, many rural districts have lost their most talented teachers and principals to neighboring, less rural districts which can offer more attractive salaries and stipends. Geographically isolated rural districts are not often destinations of choice for high-performing school leaders. Finally, with a barebones central or district office staff, many rural districts lack the administrative capacity and infrastructure to train their own principals. Without help, these districts face a constant struggle to train and retain highquality school leaders and teachers.

Geographic isolation remains a factor in recruitment and retention of highly qualified principals in rural schools. In the August 2010 edition of Education Week, "Efforts to Build Rural Leadership Gain Steam”, Jerry Johnson, research director for the Rural School and Community Trust, stated, "Rural schools on average, face higher concentrations of the challenges that make schools more difficult to staff than do their counterparts in other locales" [1]. In the United States, federal and 
state mandates to reconstitute or restructure persistently failing schools, in some cases by replacing the teachers and administrators, can exacerbate these personnel shortages. Attempts to recruit and retain highly qualified and effective leaders to these rural areas are problematic because of the shortage of turnaround school leaders in rural areas and increasing pressure to produce quick results in a short amount of time [2].

In an effort to meet this challenge and to create a pool of highly qualified school leaders, some rural schools in the United States are utilizing lessons learned from effective succession planning in the private sector and in the military to identify and train cadres of "home-grown" school leaders to serve in their districts. Singapore, Hong Kong, Finland, and Japan have well-established systems to identify leadership potential and then support intensive training of school leaders. A recent report from Learning First analyzed principal training in Ontario, Singapore, Hong Kong, and Shanghai and found that each system had a well-designed, intentional approach to leadership development, including training and development aligned with the vision of the system, identifying and grooming teachers for leadership roles, creating training programs that emphasize problem-solving skills, and ensuring ongoing professional development continues throughout a principal's career [3].

A study of succession planning asserted that "incorporating succession plans and processes into all school improvement plans and processes will push all administrators and those around them to take the long-term challenges of succession and sustainability more seriously" [4]. However, many districts simply do not have the capacity or human capital to develop and sustain a robust leadership pipeline. Strategic university-district partnerships and additional support from the government could assist districts, especially smaller, rural districts, meet their leadership staffing needs. In North Carolina, many of the lowest performing schools in the state are disproportionately clustered in rural areas. These districts need access to a pool of wellqualified candidates to lead schools and to better serve our nation's neediest children.

In this article, we highlight the key elements of a radically different preparation program to train aspiring school leaders specifically to work in rural areas and in rural contexts. Recognizing the importance of having a great principal in every school while also having concerns about administrative turnover and leadership capacity, superintendents from 14 rural counties in North Carolina, and faculty from North Carolina State University, collaborated to establish a formalized partnership designed to build leadership capacity and ensure a pool of high-quality principals and assistant principals. Utilizing research-based best practices, faculty developed a rural school leadership preparation and succession model that is the basis of NC State's Northeast Leadership Academy (NELA). In many school districts, particularly small, rural districts, teacher staffing is generally the extent of human capital planning with little to no attention paid to leader development and succession planning. In 2010, NC State's NELA program was reenvisioned as a solution to the stubborn problem of recruiting and retaining effective leaders for historically low performing, rural schools. NCSU anchored the redesign around our beliefs and values as expressed in our motto: "Excellent Leaders: Effective Schools: Enriched Communities (C.”

North Carolina State's Northeast Leadership Academy serves 14 rural school districts in Northeast North Carolina, but is nationally recognized in the U.S. for its innovation and quality. NELA was selected by the University Council for Educational Administration (UCEA) to receive its Exemplary Educational Leadership Preparation Program Award (one of only five programs in the U.S. to have ever received this distinction). UCEA is a consortium of the nation's leading leadership preparation programs and is committed to advancing the preparation and practice of educational leaders. Its Exemplary Educational Leadership Preparation Program Award was established to celebrate exemplary programs and encourage their development. In this paper, we detail the development and unique features of this innovative way of preparing school leaders to serve in rural, high-poverty, high-need schools.

Research clearly demonstrates that principals have more of an impact on student achievement in high-poverty, rural schools than principals in less challenging schools [5]. Value-added student test scores are nearly twice as large in high-poverty schools as in low-poverty schools [6]. High-poverty, low-achieving schools, which need the very best principals, often have great difficulty attracting high quality applicants [7].

North Carolina State University (NCSU) chose to develop a school leadership program targeted at preparing high quality principals to lead rural schools. The NELA program serves the following 14 partner school districts: Bertie, Edgecombe, Franklin, Granville, Halifax, Hertford, Martin, NashRocky Mount, Northampton, Roanoke Rapids, Vance, Warren, Washington, and Weldon City. Beginning with a small development grant from the Bill and Melinda Gates Foundation and with support from the North Carolina Department of Public Instruction (NCDPI), NELA was brought to scale through an infusion of more than $\$ 6.2$ million in federal Race to the Top funds.

The program is based on research-based best practices, including the North Carolina Standards for School Executives, the work of the New York City Leadership Academy's Principals Excellence 
Program (PEP), and Kentucky's Collaborative Model for Developing School Leaders for Rural High-Need Schools Program; however, it is tailored to the specific leadership needs of the rural districts it serves. Program graduates must make a three-year post-degree commitment to work in high-need schools in one of the 14 targeted districts and the districts have agreed to hire the academy's graduates first when assistant principal and principal jobs open. According to Bonnie Fusarelli, the Director and Principal Investigator on the grant, "Growing skilled rural school leaders from within permanently strengthens rural schools . . . You can't understand the complexities of the community from the outside; you can't go in from the outside and 'fix it'. It won't be sustainable; it won't be authentic" [8].

Derived from researched-based best practices, NCSU's faculty, with input from an advisory team composed of stakeholders from North Carolina's P12 educational system including current and retired principals, superintendents, the state department of public instruction, and professional development organizations, collaboratively developed a new model of preparation, early career support, and continuous professional development for leaders who have the desire and commitment to lead high need schools. As a testament to the success of the model, NELA has received two additional grants from the U.S. Department of Education, NELA 2.0 and the NELA-District and School Transformation grants, totaling \$6.6 million to further develop, refine, and expand efforts to recruit and train school leaders for high-poverty, rural schools. Additionally, faculty at NC State have received two grants from the state department of education and a grant from The Wallace Foundation (totaling over $\$ 8.5$ million) to expand and modify the model for different school contexts.

\section{A radically different approach to rural school leadership development}

The question of how best to prepare school leaders-how to take teachers who aspire to lead schools and effectively train them for school leadership positions-has been a topic of much debate and reform over the past half century in the U.S. In the 19th century, little to no training was provided to aspiring school leaders-principals were expected to teach as well as to administer the school and no specialized knowledge base or set of skills had been developed. With the advent of the industrial revolution and the emergence of administrative science, the preparation of school leaders in the U.S. became more formalized and structured. As with all scholarly fields, as educational administration developed into a legitimate area of scientific inquiry, the training and preparation of school leaders became more scientific and theory-driven as the knowledge base developed-away from retired administrators retelling old war stories of their experiences and toward theory-informed, research-based best practices.

Not surprisingly, as the field moved further and further from the daily life of schooling, criticisms of university-based leadership preparation emerged. Common criticisms included an over-reliance on theory divorced from practice, instruction by too many university faculty who lacked experience as school leaders, lack of practical relevance of coursework, and inadequacies in the field-based internship. Such criticisms are not uncommon not only in the U.S. but abroad as well. The NELA program is radically different from traditional school leadership development programs and was intentionally created to address these criticisms. The rigorous, research-based, and field-based program requires participants to demonstrate their leadership skills through solving authentic school problems with the support of faculty, principal mentors, and executive coaches. These executive coaches serve as additional mentors (in effect, creating nested layers of support) to the aspiring school leaders and are incredibly valuable resources to novice school leaders; 95 percent of graduates serving as principals or assistant principals credit their executive coaches with improving their leadership skills and practices. NELA teaches participants powerful mindsets and skill sets that enable them to change the trajectory of historically low-performing rural schools. Program experiences are customized to focus on turnaround principles for rural, low performing, high-poverty schools and communities.

\subsection{What makes NELA unique?}

Effective programs present relevant leadership theory, have curricular coherence, provide experience and the practical application of theory into practice in authentic contexts, use cohort groupings, coaches, and mentors, offer a full-time year-long internship or field experience, expose students to models of effective schooling in different contexts, and engage in meaningful collaboration between the program and schools for program planning, assessment, and improvement. These practices are also consistent with literature on executive development and adult learning theory. These elements were included in the NELA curriculum design. NELA's intensive, highlyselective cohort model combines coursework with supervised principal residency experiences and places an emphasis on connecting to the local community. Student engage in action research to collect and analyze data in schools, as opposed to writing theoretical papers disconnected from practice. Each level of activity and service is designed to create a comprehensive, sustained 
approach to embedded, research-based professional development. NELA is undergirded by the following beliefs about effective leaders. An effective principal: 1 . is a leader of learning in the school (all decisions and resources are aligned to the goal of improving student outcomes); 2. develops the staff and cultivates a culture of continuous, reflective professional learning; 3 . cultivates distributive leadership so that authority and accountability are linked; 4. is a systems-thinker and is able to frame problems and potential problems by being a reflective practitioner; 5 . is able to identify leverage points within the system to push change efforts that improve school outcomes; 6. understands, reads, predicts, and improves the school climate; and 7. uses multiple forms of data to inform all decisions.

\subsubsection{Strategic recruitment and performance-} based selection. Much like models of succession planning used in the private sector and in the military, NELA employs an intentional strategy of recruitment and selection. Traditionally, universitybased school leadership preparation programs utilize a self-select model for recruitment; selection typically involves simply completing the application process and taking a standardized test such as the Graduate Record Exam (GRE). NELA utilizes a multi-step selection process that includes a daylong Candidate Assessment Day full of experiential events in which candidates must demonstrate their skills, knowledge, and dispositions. University-based preparation programs are often criticized for low admissions standards and lack of selectivity. However, university faculty who are involved in the NELA program work in partnership with school superintendents, other district leaders, and principals to identify highly talented teachers whom they believe have excellent potential to be school leaders. Upon completing the standard graduate school application, which includes background screening and reference checks but excludes standardized graduate school admissions tests such as the GRE which have no predictive value for school leadership, a NELA Project Interviewing Team consisting of professional, experienced, and effective educational leaders reviews the candidates' application materials, then invites the finalists to participate in NELA's Candidate Assessment Day, which consists of: (a) a one-on-one individual interview with a successful, experienced educator; (b) two role playing exercises using scenarios including a post conference evaluation of a teacher and a role play with a difficult student (evaluated by a team of faculty, experienced principals, superintendents, and students); (c) a school improvement process teaming exercise; (d) a timed writing exercise in which candidates write an emergency 1-page memo to parents in response to a school crisis; (e) an instrument designed to measure grit (grit scale); and (f) a test to assess candidates' humility and dispositions toward servant leadership. Reviewers utilize rubrics to score each candidate's performance on all exercises. Faculty tally each candidate's rubrics and collectively discuss the potential for the candidate to become an effective school leader. Additionally, faculty consult with districts and superintendents before offering admission to top candidates. Although the multi-layered review process is time-consuming and requires a commitment by faculty, practicing administrators, and superintendents well beyond the usual review process, it has proven invaluable in presenting a more holistic, comprehensive picture of applicants, beyond test scores and GPA. Some candidates who look good on paper fail miserably on evaluations of the interpersonal skills and dispositions essential to lead school turnaround. Others lack the maturity or in-depth knowledge of the teaching and learning process and are encouraged to apply for future cohorts once they gain those essential experiences.

2.1.2. Core elements of the program. Once students (called "fellows") have been admitted into the program, their intense preparation for school leadership begins. The process is designed to transform teachers into holistic, thoughtful, rigorous school leaders. The core elements of the training include: (a) leaders of literacy and instructional leaders in digital learning environments; in partnership with North Carolina State University's Friday Institute for Educational Innovation, aspiring principals learn how to become instructional leaders in digital learning environments. Specialists in literacy are hired to provide intensive instruction on all facets of literacy, including how to deliver effective, high quality instruction to students who are dyslexic; (b) specialized trainings such as facilitative leadership, crucial conversations, conflict resolution, digital storytelling, Common Core, understanding by design, Covey leadership training, and restorative justice, among others. Through a series of semesterlong field-based projects, fellows also learn about child, adolescent, and adult developmental and cognitive psychology; (c) uses cohorts as a strategy to build trusting relationships, expand collegial networks, and develop high-performing school leadership teams; (d) utilizes a mix of university faculty and exemplary current and retired school leaders, ensuring an integration of research-based knowledge and practitioner knowledge; (e) students engage in solving authentic problems of practice in high need schools; for example, participants learn school law by creating and delivering professional development for teachers around legal concepts as opposed to memorizing legal cases or writing a legal memo as is often the requirement in traditional programs; (f) utilizes field-based, instructional rounds--clinical sites and rotational field residencies 
where aspiring leaders have multiple experiences in each of the following settings: elementary school, middle school, high school, central office, and community-based organizations; (g) site visits to high performing, high poverty schools in North Carolina and other states, including visits to public, private, religious, and charter schools. The most effective response to parochialism ("that will never work here" and/or "this too shall pass" attitudes) is to surround practitioners with examples of individuals and schools that have managed to produce significant improvement with demographically similar populations; (h) full-time summer community internship in which participants complete a six-week internship in a community agency and develop and deliver professional development for teachers, create resources for parents and teachers, and write grant applications to fund needed programs, connecting the school to the community; (i) executive coaching and mentoring in which fellows are paired with both a school-based principal mentor and an executive coach (retired expert principals and superintendents); fellows are supported over their principal residency year and post-degree during their first two years as school leaders. We have learned from the business model that effective executive coaching helps leaders retain key subordinates (in education the key subordinates would be effective teachers) but it must be both strategic and individualized. Executive coaching is not something typically found in university-based programs. NELA trains coaches using a blended coaching framework before they work with the NELA fellows. The coaches are selected based on their recognized excellence as leaders in the field and participate in a customized coaching training program provided by leadership coaching experts from NC State. The coaches work with NELA fellows as they are hired into leadership positions. New principals/assistant principals participate in monthly sessions facilitated by NELA coaches during their first year in leadership. Monthly sessions focus on leadership skills, managerial issues, relationship building, and instructional leadership; (j) a yearlong, full-time principal residency in the second year; students are granted provisional licenses as an assistant principal, which enables them to perform all the functions of an assistant principal while still in their residency, including teacher observations and evaluations. In addition, students continue to participate in professional development seminars held throughout the year that build upon and strengthen their skills, knowledge, and dispositions. These trainings include crucial accountability, technology and culture training, and advanced Covey leadership training, among others. Fellows also practice interviewing and resume writing and go through a formative assessment day which gives them the opportunity to demonstrate and apply what they have learned, as well as to receive feedback from practicing school leaders and university faculty and (k) early career and transitional support. Developing effective principals must continue beyond completion of preservice preparation programs, placement as school leaders, and support during novice practice years [9].

\subsection{Program performance}

NELA graduates make a three-year, post-degree commitment to work in high needs, rural schools. NELA was envisioned as a solution to the stubborn problem of recruiting and retaining strong leaders for historically low performing rural schools. Research shows it takes approximately five years to put a teaching staff in place as well as fully implement policies and practices that will positively impact the school's performance [10], yet NELA graduates serving as principals have documented notable improvements during their first year and those gains continue in schools with a NELA principal for two consecutive years. Students in failing, high poverty schools typically lose ground and have reading and math achievement that is .02-.06 standard deviations lower in years when they have a new principal. Research indicates that the negative effect of new principals on student achievement is especially large when schools have a first-time new principal (one without prior experience at other schools) [11].

The negative relationship between principal turnover (having a new principal) and achievement is stronger in failing schools, high poverty schools, and schools with more novice teachers (all of which are characteristics of the schools led by NELA principals) [12]. Typically, new principals experience a dip in scores, yet the NELA principals had improvements in student achievement scores [13]. The achievements of the NELA principals are particularly impressive when viewed with this research in mind. To date, graduates of the NELA program have performed exceedingly well in terms of their success in securing school leadership positions as assistant principals and principals; over 90 percent of graduates are hired into leadership positions within one year of program completion, compared to a national average of less than 50 percent. In addition, more than 90 percent of program graduates serving as principals were rated effective by teachers, staff, and students at the end of their first year as principal and over 95 percent were rated as "accomplished/effective" or "distinguished/highly effective" on the North Carolina Standards for School Executives evaluation instrument.

In addition to the UCEA award, the NELA leadership development model for rural schools has been recognized at the local, state, and national levels by organizations at the vanguard of educational leadership preparation as well as in in 
journal publications and by media outlets including: The Wallace Foundation, Center for American Progress, National Association of State Boards of Education, Education Week, The University Council for Educational Administration (UCEA), Journal of Planning and Changing, North Carolina Public School Forum, and many others.

\section{Lessons learned}

We have learned many lessons in our efforts to improve the effectiveness of training principals to lead high poverty, rural schools. Two key lessons are discussed below. The first lesson is the importance of building strong relationships with school district leaders, including superintendents and district office staff. Leadership development is not the sole province of university-based preparation programs and requires the establishment of effective partnerships between universities and school districts. It is also critical to maintain and strengthen these partnerships, since key personnel change over time. Recently, one of the key superintendents in the NELA consortium left for a position in another district. Fortunately, we had developed a very good relationship with his successor. Relationship building and maintenance is an ongoing, time-intensive endeavor but is essential to the sustainability of programs and partnerships.

A second lesson learned is the importance of using formative and summative assessment data in continuously improving our training program. We regularly solicit feedback from students currently undergoing training as well as program graduates, school principals, superintendents, and faculty. As such, the program is constantly evolving and improving, as we take what has worked, change was hasn't, and constantly seek ways to improve our preparation, including keeping abreast not only of recent research in leadership development in education, but also developments in leadership development and training in other disciplines such as business, public administration, and leadership studies. We believe these efforts will keep us on the cutting edge of leadership training and development and allow us to continuously improve this model of rural school leadership development.

\section{References}

[1] Schulken, M., (2010). Efforts to build rural leadership gain steam. Education Week. Retrieved from http://www.edweek.org/ew/articles/2010/08/04/37rural.h2 9.html

[2] Schulken, M., (2010). Efforts to build rural leadership gain steam. Education Week. Retrieved from http://www.edweek.org/ew/articles/2010/08/04/37rural.h2 9.html
[3] Sparks, S. D., (2017, October 19). Principal-training secrets shared by the world's top school systems. Education Week. Retrieved October 19, 2017 from http://blogs.edweek.org/edweek/inside-school-research/ 2017/10/School_leadership_training_around_the_world.ht $\mathrm{ml}$

[4] Fink, D., Brayman, C., (2006). School leadership succession and the challenges of change. Educational Administration Quarterly, 42(1), 62-89.

[5] Waters, J. T., Marzano, R. J., McNulty, R. A., (2003). Balanced leadership: What 30 years of research tells us about the effect of leadership on student achievement. Aurora, CO: McREL.

[6] Branch, G., Hanushek, E., Rivkin, S., (2013). School leaders matter: Measuring the impact of effective principals. Education Next, 13(1), 62-69.

[7] Hull, R., Supovitz, J., Newman, B., Prociw, S., (2015). Successful leaders for successful schools: Building and maintaining a quality workforce. Retrieved from National Association of State Board of Education Leadership development study group. Retrieved from: www.nasbe.org.

[8] Schulken, M., (2010). Efforts to build rural leadership gain steam. Education Week. Retrieved from http://www.edweek.org/ew/articles/2010/08/04/37rural.h2 9.html

[9] Fusarelli, B. C., (2008). The changing nature of leadership preparation in education. Academic Exchange Quarterly, 12(2), 13-20.

[10] Alvoid, L., Black, W. L., (2014). The changing role of the principal: How high-achieving districts are recalibrating school leadership. Retrieved from The Center for American Progress websitewww.americanprogress.org

[11] Waters, J. T., Marzano, R. J., McNulty, R. A., (2003). Balanced leadership: What 30 years of research tells us about the effect of leadership on student achievement. Aurora, CO: McREL.

[12] Orr, M. T., (2006). Research on leadership education as a reform strategy. Journal of Research on Leadership Education, 1(1), 1-5.

[13] Fusarelli, B., Militello, M., (2012). Innovative principal preparation program: What works and how we know. Planning and Changing Journal, 43(1). https://education.illinoisstate.edu/planning/articles/vol43.shtml 